\title{
PRINSIP KETERBUKAAN INFORMASI (DISCLOSURE) DALAM KEGIATAN PASAR MODAL MENURUT UU RI NO.8 TAHUN 1995 TENTANG PASAR MODAL: SUATU TINJAUAN YURIDIS
}

\author{
Anthon Nainggolan ${ }^{1}$ \\ Anthonnainggolan@yahoo.com \\ Fakultas Hukum, Universitas Kristen Indonesia, Jakarta, Indonesia
}

\begin{abstract}
Capital Market is a place to buy and sell or the stock exchanges, in general, the activity of capital market is held by the stock exchange institution, clearing institution, and other financial institutions whose activities are related to one another. One of the purpose of capital Market law is to guarantee that the activity of capital Market is done smoothly, proper and efficient and also to protect the importance or the interest of financiers and the public community. Transparancy is really needed in the activity of capital market, the meaning of transparency is (1) the nature of translucent light (2) real (3) clear or generally giving a smilar mean of transparent or visibility.
\end{abstract}

\section{Kata Kunci: Prinsip Keterbukaan Informasi}

\section{Pendahuluan}

Untuk memenuhi kebutuhan hidup, manusia melakukan berbagai upaya yang disebut sebagai kegiatan ekonomi. Awalnya kegiatan ekonomi dilakukan hanya untuk memenuhi kebutuhan dasar. Bila pemenuhan tersebut masih menyisakan dana maka orang akan cenderung berupaya menyimpannya di tempat yang mereka anggap paling aman dan menguntungkan. Tempat tersebut pada umumnya disebut dengan bank. Tetapi dikarenakan perkembangan zaman maka selain bank masih terdapat tempat yang menguntungkan dalam penyimpanan uang tersebut yaitu pasar uang.

Pada lembaga perbankan bentuk penyimpanan uang tersebut dapat berupa tabungan deposito. Bila tabungan sudah cukup banyak, masyarakat akan mencari inisiatif lain dalam upaya peningkatan uang yang dimilikinya. Alternatif lain tersebut adalah melakukan investasi modal. Ada yang berinvestasi dalam bentuk tanah, rumah atau emas, dan ada dengan turut menanamkan modalnya pada suatu perusahaan. Berinvestasi dalam bentuk menanamkan modal adalah pemilik modal turut mengelola dan menjalankan perusahaan yang sahamnya mereka miliki.

\footnotetext{
${ }^{1}$ Dosen tetap FH UKI.
}

Ada pula yang berinvestasi di pasar modal dengan instrument berupa saham, obligasi atau yang lain. Disini pemilik tidak turut campur dengan ak- tivitas sehari-hari, tetapi mereka lebih berkepentin- gan pada deviden dengan keuntungan modal (capital gain) dari dalam.

Salah satu fungsi yang memacu perkembangan ekonomi nasional adalah pasar modal. Fungsi strategi dan pentingnya pasar modal membuat pemerintah amat berkepentingan atas perkembangan dan kemajuan pasar modal karena berprestasi menghimpun dana secara pasif, sehingga dapat dimanfaatkan untuk memperbesar volume kegiatan pembangunan.

Pengertian pasar modal sebagaimana pasar konvensional pada umumnya adalah merupakan tempat bertemunya penjual dan pembeli. pasar (market) merupakan sarana yang mempertemukan aktifitas pembeli dan penjual untuk suatu komoditas atau jasa. Pasar modal mempertemukan pemilik dana dengan pengguna dana untuk tujuan investasi jangka menengah dan panjang. Kedua belah pihak melakukan jual beli modal yang berwujud efek pemilik dana menyerahkan surat bekti kepemilikan berupa efek.

Berdasarkan uraian di atas maka dapat dilihat suatu kenyataan bahwa masyarakat luas dapat berinvestasi melalui pasar modal dengan memiliki pada 
perusahaan mana ia akan menanamkan modalnya. Dan pada umumnya perusahaan yang terlibat dalam penjualan sahamnya di pasar modal adalah berbentuk perseroan terbatas. Perseroan Terbatas (PT) terbagi atas 2 (dua) jenis yaitu: Perseroan Terbatas Terbuka dan Perseroan Terbatas Tertutup.

Perseroan Terbatas Terbuka adalah suatu PT dimana masyarakat luas dapat serta menanamkan modal dengan cara membeli saham yang ditawarkan oleh PT Terbuka melalui bursa dalam rangka memupuk modal untuk investasi PT, atau dewasa ini biasa disebut "PT yang go public".

Dalam Undang-Undang Perseroan Terbatas pengertian perseroan terbuka tercantum pada pasal 1 ayat (6) yang berbunyi sebagai berikut:

\section{Perseroan Terbuka adalah perseroan:}

1. Yang modal dan jumlah pemegang saham memenuhi kriteria tertentu.

2. Atau perseroan yang melakukan penawaran umum yang sesuai dengan peraturan perundangundangan dibidang pasar modal, seperti:

3. Emisi, operasi penunjang dan lembaga penunjang untuk melakukan penawaran umum.

4. Selanjutnya perusahaan menyiapkan dokumen dan perjanjian yang diperlukan untuk melakukan penawaran umum.

5. Perusahaan menyiapkan semua dokumen dan perjanjian yang diperlukan untuk melakukan penawaran umum.

Masyarakat yang akan menanamkan modalnya melalui pasar modal di sebuah perusahaan haruslah memiliki prinsip yang berhati-hati sehingga dana yang ditanamkan tersebut tidak menjadi kerugian padanya. Untuk melindungi masyarakat tersebut maka UndangUndang RI No. 40 Tahun 2007 tentang Perseroan Terbatas menganut suatu prinsip bahwa perusahaan yang menawarkan sahamnya tersebut harus memiliki prinsip keterbukaan informasinya (disclousure) perusahaan tersebut. Setiap perusahaan yang akan menawarkan di pasar modal harus melalui tahap antara lain:

\section{Tahap Pra Emisi}

Adalah tahap dimana perusahaan melakukan pengkajian secara mendalam tentang keadaan keuangan, aset, kewajiban pada pihak lain terha- dap perusahaan penghimpun dana. Pada tahapini perusahaan ini harus leksbutisasi dalam bidang permodalan keuangan, aset, organisasi tertentu dijajaran eksekutif dan komisaris dari legal audit ini akan diketahui jumlah dan status aset yang dimiliki oleh perusahaan maupun hutang perusahaan terhadap pihak lain yang semuanya ini dilakukan oleh legal audit atau akuntan publik.

Adapun tahapan-tahapan dalam Pra Emisi ini adalah sebagai berikut:

a. Perusahaan menyusun penawaran umum yang harus mendapat persetujuan dari Rapat Umum Pemegang Saham (RUPS), RUPS akan menjadi landasan hukum untuk melakukan penawaran.

b. Setelah perusahaan menyusun perencanaan umum maka diperlukan lembaga Penjamin emisi, profesi penunjang dan lembaga penawaran umum.

c. Selanjutnya perusahaan menyiapkan dokumen dan perjanjian yang diperlukan untuk melakukan penawaran umum.

d. Perusahaan menyiapkan semua dokumen dan perjanjian yang akan diperlukan untuk penawaran umum.

e. Perusahaan membuat kontrak pendahuluan dengan bursa efek.

f. Perusahaan melakukan public ekspose.

g. Perusahaan menyampaikan pernyataan kepada Bapepam.

\section{Tahap Emisi}

Tahap emisi adalah penawaran oleh sindikasi penjamin emisi dan agen penjualan di pasar primer dan penjatahan kepada pemodal oleh sindikasi penjamin emisi dan emiten di pasar primer, selanjutnya perusahaan mencatatkan efeknya di pasar modal di pasar bursa dengan sekaligus memperdagangkan efek tersebut di pasar bursa.

3. Tahap Setelah Emisi

Tahap setelah emisi adalah setelah proses emisi selesai maka perusahaan emiten berkewajiban menyampaikan informasi perusahaannya dengan membuat antara lain:
a. Laporan Berkala
b. Laporan Tahunan
c. Laporan Tengah Tahunan, dan
d. Laporan Kejadian 
Keempat laporan tersebut penting terjadi didalam suatu perusahaan, misalnya terjadi suatu akuisisi atau penggantian direksi. emiten perusahaan public atau pihak lain yang terkait menyampaikan informasi penting yang berkaitan dengan tindakan atau efek perusahaan tersebut pada waktu berkala peristiwa penting (Undang-Undang Pasar Modal No. 8 Tahun 1995, Pasal 86 ayat 1). Emiten wajib melakukan informasi secara lengkap dan akurat, dikatakan lengkap jika informasi yang disampaikan tersebut tidak ada yang disembunyikan, disampaikan atau tidak menyampaikan apa-apa atas fakta material yang dikatakan akurat jika informasi yang disampaikan mengandung kebenaran dan ketetapan. Setiap pihak yang berkaitan diwajibkan untuk mempertanggungjawabkan kerugian yang ditimbulkan akibat penyampaian informasi tersebut, Undang-Undang Pasar modal No. 8 Tahun 1995 Pasal 80 ayat (1) menyebutkan sebagai berikut:

1) Pihak yang menandatangani pernyataan pendaftaran,

2) Direktur atau komisaris emiten pada waktu pernyataan pendaftaran dinyatakan efektif,

3) Penjamin pelaksanaan emisi efek, dan

4) Profesi penunjang pasar modal atau pihak lain pendapat atau keterangan dan atas persetujuannya dimuat dalam pernyataan pendaftaran.

Pelanggaran terhadap pelaksanaan prinsip keterbukaan itu Bapepam akan mengadakan sanksi administratif dan pidana.

\section{Permasalahan}

1) Bagaimanakah penerapan prinsip keterbukaan informasi (disclosure) diwujudkan pada sebuah perusahaan yang akan melakukan penawaran di pasar modal menurut Undang-Undang RI No. 8 Tahun 1995.

2) Bagaimanakah tanggung jawab hukum perusahaan emiten jika melanggar prinsip keterbukaan menurut Undang-Undang RI No. 8 Tahun 1995.

\section{Tujuan Penulisan}

1) untuk mengetahui apakah prinsip keterbukaan

(disclosure) telah dijalankan oleh pihak-pihak yang terkait dalam prakteknya.
2) untuk mengetahui apakah prinsip keterbukaan (disclosure) dari aspek hukum sudah menjamin investor melakukan investasi.

\section{Keterbukaan Informasi}

Keterbukaan dalam transaksi efek adalah seluruh informasi mengenai keadaan usahanya yang menjadi aspek keuangan, hukum, manajemen dan harta kekayaan perusahaan yang akan melakukan emisi saham calon investor dapat memahami dan memutuskan kebijakan untuk investasinya.

Tinjauan dari prinsip keterbukaan tersebut adalah untuk terciptanya efisiensi dalam transaksi efek. Perdagangan yang efisien adalah perdagangan dimana para pihak yang berkepentingan dengan perdagangan efek tersebut dapat melakukan perdagangan dengan mudah, cepat dan dengan biaya yang relatif murah, termasuk didalamnya adanya penyelesaian transaksi yang cepat dan murah. ${ }^{2}$

Pengertian tentang prinsip keterbukaan ditemukan dalam Pasal 1 ayat (25) Undang-Undang No. 8 Tahun 1995 tentang Pasar Modal menentukan prinsip keterbukaan adalah pedoman umum yang mensyaratkan emiten, perusahaan publik dan pihak lain yang tunduk pada Undang-Undang ini adalah untuk menginformasikan kepada masyarakat dalam waktu yang tepat seluruh informasi materil mengenai usahanya atau efeknya yang dapat berpengaruh terhadap keputusan pemodal terhadap efek yang dimaksud dan atau harga efek tersebut.

Hukum pasar modal dengan demikian memberikan porsi yang sangat penting terhadap perlindungan investor ini. Perlindungan ini terutama dilaksanakan melalui 2 (dua) cara yaitu:

1. Melalui Mekanisme Transparansi Informasi (Full disclosure Principle)

Prinsip full disclosure yang sering juga disebut sebagai dasar dari disclosure regulation ini didasarkan pada dua asumsi dasar, yaitu yang pertama adalah orang dewasa yang dapat membuat keputusan terbaik untuk mereka sendiri. Seandainya semua informasi telah sepenuhnya dibeberkan oleh emiten maka investor akan menentukan apakah membeli atau menjual sekuritas

\footnotetext{
${ }^{2}$ Sofyan A Djalil, Perlindungan Investor Di Pasar Modal, Yogyakarta: Fakultas Hukum Universitas Gadjah Mada, 1997, hal 13
} 
tertentu atau tidak bertransaksi sama sekali. Karena mereka membuat keputusan berdasarkan informasi yang cukup jelas maka mereka bertanggung jawab atas keputusa tersebut.

Prinsip full disclosure ini adalah bentuk perlindungan investor yang dilakukan oleh pemerintah secara tidak langsung. Pemerintah atau otoritas pasar modal dalam hal ini pada prinsipnya hanya berusaha menjamin bahwa investor mendapat informasi yang selengkap-lengkapnya dan sejelas mungkin. Otoritas pasar akan mewajibkan emiten untuk selalu memberikan informasi yang lengkap, jelas dan tepat waktu kepada masyarakat. Dalam hal ini otoritas pasar mewajibkan emiten yang akan melakukan penawaran umum harus menyampaikan pendaftaran, menyampaikan laporan regular dan juga menyampaikan laporan setiap kejadian penting. Dengan demikian pada hakekatnya ada tiga tahap informasi yang wajiba disebarkan oleh emiten, adalah: ${ }^{3}$

a. Informasi pada saat perusahaan melakukan penawaran umum,

b. Informasi regular, berupa laporan triwulan dan tahunan, dan

c. Informasi tentang kejadian penting yang terjadi.

2. Larangan Manipulasi Termasuk Larangan Insider Trading

Perlindungan investor di pasar modal dalam system disclosure regulation (keterbukaan dalam transaksi) pada intinya bertumpu pada keterbukaan informasi. Namun dalam dunia nyata perlindungan yang demikian tidak mencukupi. Berbagai pihak yang terlibat di pasar modal masih mungkin melakukan berbagai tindakan yang dapat merugikan investor, baik berupa kecurangan dalam melakukan transaksi, penipuan dalam mengemukakan informasi dan kejahatan dalam perdagangan.

Di samping itu orang-orang yang mempunyai akses eksklusif terhadap informasi tertentu (informasi oang dalam) dimana orang lain belum mengetahuinya juga dapat mengambil manfaat

\footnotetext{
${ }^{3}$ Najib A Gismar, Insider Trading Dalam Transaksi Efek, Bandung: Citra Aditya Bakti, 1999. hal 78
}

financial dengan melakukan perdagangan dengan menggunakan informasi tersebut. Hal ini menciptakan ketidak adilan terhdap orang lain yang tidak mempunyai informasi tersebut. Oleh karena itu investor juga perlu dilindungi dari berbagai tindakan curang, manipulasi, dengan mempergunakan informasi orang dalam tersebut. Untuk itu hukum secara sangat intensif atas masalah ini.

\section{Pasar Modal}

Secara sederhana dapat dikatakan bahwa pasar modal, sebenarnya sama dengan pasar-pasar lain pada umumnya yaitu sesuai dengan namanya ada- lah tempat berlangsungnya kegiatan jual-beli. Yang membedakan pasar modal dengan pasar lainnya adalah objek yang diperjualbelikan di tempat itu.

Asril Sitompul menyebutkan bahwa pengertian pasar modal ini yang dalam terminologi bahasa Inggris disebut Stock Exchange atau Stock Market adalah "An organized market or exchange where shares (stock) are traded" yaitu pasar yang terorganisir dimana efek-efek diperdagangkan. ${ }^{4}$

Undang-Undang RI No. 8 Tahun 1995 tentang Pasar Modal dalam Pasal 1 ayat (13) mengatakan bahwa pasar modal adalah kegiatan yang bersangkutan dengan penawaran umum dan perdagangan efek, perusahaan public yang berkaitan dengan efek yang diterbitkan serta lembaga dan profesi yang berkaitan dengan efek. Di negara-negara maju pasar modal sudah sejak lama merupakan lembaga yang sangat diperhitungkan bagi perkembangan ekonomi Negara, oleh sebab itu Negara selalu berkepentingan untuk turut mengatur jalannya pasar modal.

Kegiatan pasar modal pada umumnya dilaku-kan oleh lembaga-lembaga antara lain pusat perdagangan sekuritas atau resminya disebut bursa efek (stock market), lembaga kliring dan lembaga-lembaga keuangan lainnya yang kegiatannya terkait satu dengan yang lainnya, Bursa efek terdapat hampir di setiap Negara. Di USA ada New York Stock Exchange (NYSE), di Inggris London Stock Exchange (LSE), di Singapura Stock Exchange Singapore (SES), di Nederland ada Amsterdam Stock Exchange, bahkan di

\footnotetext{
${ }^{4}$ Asril Sitompul, Pasar modal Penawaran Umum dan Permasalahannya, Bandung : Citra Aditya Bakti, 1996 hal 3
} 
Indonesia terdapat di dua kota yaitu Bursa Efek Jakarta (Jakarta Stock Exchange (JSE) dan Bursa Efek Surabaya, Surabaya Stock Exchange (SES).

Seperti telah disebutkan di atas pasar modal atau bursa efek secara sederhana adalah tempat bertemunya pembeli dan penjual efek yang terdapat di bursa efek itu (Listed Stock), pembeli dan penjual datang untuk mengadakan transaksi jual-beli efek. Oleh karena transaksi dilakukan di suatu tempat yang tertentu, maka diharapkan transaksi bisnis yang terjadi antara penjual dan pembeli menciptakan harga yang wajar berdasarkan permintaan dan penawaran. Hal ini sesuai dengan tujuan dibentuknya bursa efek yaitu menyelenggarakan perdagangan efek yang tertib dan wajar, untuk itu bursa efek mempunyai kewajiban mengawasi kegiatan angota-anggotanya. Di Indonesia, anggota bursa efek tersebut merupakan pemegang saham bursa efek karena di Indonesia Bursa Efek didirikan dalam bentuk Perseroan Terbatas, namun dengan demikian perusahaan efek yang berhak menjadi anggota bursa efek adalah perusahaan efek yang dikeluarkan oleh Badan Pengawasan Pasar Modal (Bapepam). Keanggotaan pada bursa efek ini, sangat penting bagi perusahaan efek, karena tanpa keanggotaan mereka tidak dapat melakukan perdagangan efek di lantai bursa.

Di antara tujuan dari hukum pasar modal adalah untuk menjamin terselenggaranya kegiatan pasar modal yang teratur, wajar dan efisien serta melindungi kepentingan pemodal dan masyarakat. Perlindungan pemodal salah satu pilar yang sangat penting, karena investor tidak mendapatkan perlindungan yang cukup memadai, maka mereka, terutama investor kecil, enggan untuk melakukan transaksi di bursa. Tanpa adanya jumlah investor yang cukup banyak maka kegiatan pasar akan lesu dan fungsi dari pasar modal tidak akan berkembang. ${ }^{5}$

Pada hakekatnya yang diperjualbelikan di pasar modal bukanlah barang biasa tetapi efek atau sekuritas yang tidak mempunyai nilai intrinsink. Sekuritas adalah bukti klaim seseorang atas kekayaan perusahaan yang menerbitkan sekuritas tersebut. Nilai intrinsink dari selembar saham misalnya adalah nilai

\footnotetext{
${ }^{5}$ Himpunan Peraturan Pasar Modal Mo.8 Tahun 1995 Tentang Pasar Modal, Jakarta:Sinar Grafika,1996
}

atau harga dari kertas itu sendiri yang sangat rend- ah (jika ada yang mau membeli) tidak lebih dari itu. Oleh karena itu yang menentukan nilai dari sekuritas adalah sistem hukum yang menjadi infrastruktur dari sekuritas tersebut. Jika hukum tidak memberikan kepastian perlindungan kepada investor dan orang yang memiliki sekuritas tidak dapat melaksanakan haknya yang tercantum dalam sekuritas tersebut maka sekuritas tidak bernilai sama sekali.

Sejalan dengan perkembangan perekonomian yang didukung oleh peningkatan teknologi komunikasi itu, maka semakin meningkat pula upaya berbagai perusahaan untuk mengembangkan usahanya, dan melakukan kegiatan dalam rangka meraih dana untuk ekspansi bisnis dengan berbagai cara yang tentunya membuat kegiatan perekonomian hampir diseluruh dunia termasuk di Indonesia juga mengalami peningkatan yang sangat pesat.

Semakin berkembangnya kegiatan pengembangan prusahaan ditingkat global yang tentunya membutuhkan dana yang sangat besar, maka perusahaan semakin giat mencari sumber-sumber yang dapat menyediakan dana dalam jumlah yang sangat besar, untuk itu menurut pandangan para pemilik perusahaan diarahkan pada pasar modal baik dalam negeri sendiri maupun kenegara-negara lain. Hal ini menyebabkan semakin semaraknya kegiatan pasar modal dihampir seluruh Negara, baik itu dinegara-negara berkembang maupun dinegara-negara yang sudah maju. Bursa saham merupakan wadah untuk mempermudah masuknya investasi modal dari suatu $\mathrm{Ne}$ gara kenegara lain.

Sebuah perusahaan dalam rangka mengembangkan maka dibutuhkan cara-cara untuk mendapatkan permodalan yang salah satunya adalah dengan cara mencari pihak lain untuk menanamkan modalnya pada sebuah perusahaan yang membutuhkan modal tersebut. Hal ini dapat dilakukan dengan menjual sebagian dari kepemilikan atas perusahaan, menjual kepemilikan dilakukan dengan berbagai cara, salah satunya adalah dengan penjualan sebagian dari saham perusahaan dalam bentuk efek kepada masyarakat luas yang dalam hal ini disebut investor atau pemodal, hal ini dikenal dengan istilah penawaran umum (go public). 
Dengan demikian maka dapat dikatakan bahwa manfaat berinvestasi di pasar modal merupakan suatu bentuk investasi didalam suatu perusahaan yang efeknya diperdagangkan di bursa saham. nvestor dapat memupuk keuntungan dari saham yang dibelinya tersebut. Sedangkan resiko dari investasi di pasar modal adalah apabila harga saham yang dimilikinya jatuh maka secara langsung berakibat kerugian atas investasinya.

\section{Penerapan Prinsip Keterbukaan}

Transparansi merupakan terminologi yang sangat penting dan prinsip yang fundamental dalam pasar modal. Dalam kamus besar bahasa Indonesia terbitan Departemen Pendidikan dan Kebudayaan Republik Indonesia, transparansi diartikan sebagai: (1) sifat yang tembus cahaya; (2) nyata; (3) jelas atau secara umum memberikan arti tembus pandang.

Transparansi, berlaku secara universal, didalam pasar modal internasional adalah merupakan suatu hal yang sangat mutlak untuk dapat dilakukan oleh semua pihak. Berbeda dengan sektor perbankan dimana prinsip kerahasiaan bank adalah hal yang mutlak ditaati, sector pasar modal menerapkan hal sebaliknya, disclosure atau keterbukaan adalah mutlak. Transparansi dalam pasar modal berarti keharusana emiten, perusahaan publik, dan pihak lain yang tunduk kepada Undang-Undang Pasar Modal untuk menginformasikan kepada masyarakat dalam waktu yang tepat seluruh informasi material mengenai usahanya atau efeknya yang dapat berpengaruh terhadap keputusan pemo- dal terhadap efek yang dimaksud atau harga dari efek tersebut (Undang-Undang tentang Pasar Modal No. 8 Tahun 1995 Pasal 1 angka 25). Informasi atau fakta material adalah informasi ataupun fakta mengenai peristiwa, kejadian, atau fakta yang dapat mempengaruhi harga efek pada bursa dan atau keputusan pemodal atau calon pemodal atau pihak lain yang berkepentingan atas informasi atau fakta tersebut.

Amanat mengatakan bahwa emiten perusahaan public atau pihak lain yang terkait wajib menyampaikan informasi penting yang berkaitan dengan tinda- kan atau efek perusahaan tersebut pada waktu yang tepat kepada masyarakat dalam bentuk laporan peristiwa penting (Undang-Undang tentang Pasar Modal Pasal 86 ayat 1$)^{6}$. Emiten wajib menyampaikan informasi secara lengkap da akurat, dikatakan lengkap atau informasi yang disampaikan itu utuh, tidak ada yang tertinggal atau disembunyikan, disamarkan, atau tidak disampaikan apa-apa atas fakta material. Dikatakan akurat jika informasi yang disampaikan mengandung kebenaran dan ketetapan. Kalau tidak memenuhi syarat tersebut, maka informasi dikatakan sebagai informasi yang tidak benar atau menyesatkan (Undang-Undang tentang Pasar Modal Pasal 80 ayat 1). Setiap pihak yang terkait diwajibkan untuk mempertanggungjawabkan kerugian yang ditimbulkan akibat penyampaian informasi tersebut. Pasal 80 ayat 1 Undang-Undang Pasar Modal menyebutkan pihakpihak yang bisa dimintakan pertanggungjawaban sebagai liable person atas pernyataan pendaftaran sebagaimana dikatakan oleh Abdurrahman adalah ${ }^{7}$ :

1. Pihak yang menandatangani pernyataan pendaftaran;

2. Direktur atau komisaris dari emiten pada waktu pernyataan pendaftaran dinyatakan efektif;

3. Penjamin Pelaksanaan Emiten efek;

4. Profesi penunjang pasar modal atau pihak lain yang memberikan pendapat atau keterangan dan atas persetujuan dimuat dalam pernyataan pendaftaran.

Pelanggaran terhadap pelaksanaan prinsip keterbukaan itu, Bapepam akan mengenakan sanksi administratif dan pidana. Dengan demikian tampak bahwa pengaturan mengenai keterbukaan atau transparansi ini merupakan syarat mutlak yang bersifat universal yang ditemukan dalam dunia pasar modal. Mengingat penawaran dana dalam jumlah yang amat besar dan datang dari mana saja untuk kegiatan bisnis, maka wajar kiranya keterbukaan ini menjadi prinsip yang amat diperlukan oleh investor untuk menyakinkan dirinya mendapatkan informasi yang benar dan lengkap.

\footnotetext{
Anisitus Amanat, Pembahasan Undang-Undang Perseroan Terbatas 1995 dan Penerapannya dalam Akta Notaris, Jakarta: Raj'a Grafindo Persada, 1995.hal 34

${ }^{7}$ A Abdurrahman,Ensiklopedia Ekonomi Keuangan dan Perdagangan, Jakarta Pradnya Paramita, 1991. hal 73
} 
Dikatakan transparansi atau keterbukaan ini merupakan suatu bentuk perlindungan terhadap masyarakat investor, dari segi substansial, transparan- si memampukan publik untuk mendapatkan akses informasi penting yang berkaitan dengan perusahaan ${ }^{8}$. Suatu pasar modal dikatakan fair dan efisien apabila semua pemodal memperoleh informasi yang sama (equal treatment) dalam akses informasi dari sisi yuridis, transparansi merupakan jaminan bagi hak publik untuk terus mendapatkan akses penting dengan sanksi untuk hambatan terus atau kelalaian yang dilakukan perusahaan. Pengenaan sanksi yang termuat dalam Undang-Undang Pasar Modal serta penegakan hukum atas setiap pelanggaran terhadap ketentuan mengenai keterbukaan atau transparansi ini menjadikan pemegang saham atau investor terlindungi secara hukum dari praktek-praktek manipulasi dalam perusahaan publik. Karena apabila investor tidak merasakan mendapatkan perlindungan hukum yang memadai, maka hampir dipastikan arus investasi melalui pasar modal akan kecil, kalau tidak mau dikatakan tidak ada. Perlindungan hukum tersebut memiliki dua bentuk. Bentuk pertama adalah dengan memberikan kepastian hukum melalui peraturan perundang-undangan dan penegakkannya, jaminan keterbukaan informasi akan memberikan pedomanbagi calon investor atau pemegang saham untuk mengambil keputusan, kualitas informasi akan terjaga jika keterbukaan bias dijamin.

Memberikan informasi yang salah dan setengah benar berkaitan dengan kualitas informasi, artinya informasi yang disampaikan tidak akurat atau tidak benar atau menyesatkan, yang semata-mata ditujukan sebagai window dressing untuk menarik investor, hal mana tergolong sebagai kejahatan korporasi, informasi demikian tidak memberikan gambaran dan penilaian yang memadai bagi investor untukmelakukan pembelian atau penjualan saham. Penyampaian

\footnotetext{
${ }^{8}$ A Sofyan Djalil, Perlindungan Investor Di Pasar Modal, Yogyakarta : Fakultas Hukum Universitas Gajah Mada, 1997. hal 45

${ }^{9}$ Munir Fuady, Pasar Modal Modern, Tinjauan Hukum, Bandung: Citra Aditya Bakti 1996 hal 71
}

informasi yang tidak lengkap tidak bisa dijadikan pedoman bagi investor untuk mengambil keputusan jual atau beli. Sedangkan sikap tidak menyampai- kan informasi apa-apa atas fakta material merupakan sikap yang in formal if dari emiten. Karena emiten menolak untuk memberikan penjelasan mengenai peristiwa material.

Fuady, mengatakan bahwa undang-undang pasar modal menyediakan kerangka hukum yang kokoh untuk menjamin transparansi. ${ }^{9}$ Pemberlakuan UndangUndang pasar Modal akan menjadi indikator dan landasan hukum yang diharapkan maupun memberikan perlindungan hukum kepada investor dalam hal hak untuk mendapatkan informasi yang lengkap, akurat dan benar sehingga calon investor mampu mengambil keputusan karena didukung oleh informasi yang kuat. Jaminan Undang-undang Pasar Modal akan transparansi atau keterbukaan merupakan hal yang mendasar untuk menciptakan kepercayaan dan menarik calon investor untuk berinvestasi di pasar modal. Di lain pihak, perusahaan public atau emiten yang ingin sahamnya dibeli para investor dan dapat masuk dalam standar internasional, haruslah berusaha untuk membuka diri dan menerapkan keterbukaaninformasi dengan kualitas yang terjaga dalam hal akurasi, kelengkapan, ketepatan waktu dan ketetapan informasi. Membuka diri disini berarti bersedia memberikan informasi material yang berkenaan dengan keadaan perusahaannya. Keterbukaan diartikan memberikan akses seluasnya kepada pemegang saham atau investor untuk mengetahui keadaan informasi perseroan.

Keterbukaan juga mengandung arti mengungkap semua hal secara tuntas, benar dan lengkap. Informasi yang berkualitas dapat menjadikan investor mau mengambil keputusan secara mantap, namun terdapat pertentangan batasan dan kendala untuk menerapkan keterbukaan antara investor atau pemegang saham disatu pihak dengan emiten dilain pihak, sebagaimana disebutkan dibawah ini antara lain:

1. Investor atau pemegang saham menginginkan keterbukaan yang sifatnya riil disclosure dalam mendapatkan informasi mengenai emiten, se- 
mentara emiten hanya bersedia membuka informasi hingga tingkat tertentu.

2. Investor menginginkan informasi yang tepatwaktu, sementara emiten berusaha untuk menahan informasi untuk beberapa waktu dengan alasan pengurangan biaya penyebaran dan penerbitan laporan.

3. Investor menginginkan untuk memperoleh data yang rinci dan akurat, sementara emiten hanya bersedia memberikan informasi secara garis besar.

Emiten dituntut untuk mengungkapkan informasi mengenai keadaan bisnisnya, termasuk keadaan keuangan, aspek hukum dari harta kekayaan, persoalan hukum yang dihadapai perusahaan dan manajemen. Apabila investor mengalami kerugian karena tidak memperoleh informasi yang benar, emiten bertanggungjawab untuk itu. Undang-Undang Perseroan Terbatas No. 1 Tahun 1995 Pasal 85 ayat (2) dalam pasal ini memberikan kemungkinan kepada pemegang saham untuk melakukan penuntutan atas kelalaian direksi dan komisaris untuk kerugian yang dialami oleh perseroan yang menyebabkan kerugian pada pemegang saham.

\section{Tanggung Jawab Hukum Perusahaan Emiten Jika Melanggar Prinsip Menurut Undang- Undang No. 8 Tahun 1995.}

Bapepam akan mengenakan sanksi administratif atas setiap pelanggaran terhadap peraturan-peraturan tersebut di atas oleh pihak yang telah memeproleh ijin, persetujuan atau pendaftaran dari Bapepam sebagaimana yang ditugaskan dalam Undang-undang Pasar Modal dalam Pasal 102 ayat (2), sanksi administratif dapat berupa:

a. Peringatan tertulis;

b. Denda yaitu kewajiban untuk membayar sejumlah uang tertentu;

c. Pembatasan kegiatan usaha;

d. Pembekuan kegiatan usaha;

e. Pencabutan ijin usaha;

f. Pembatalan persetujuan dan

g. Pendaftaran

Dalam menerapkan sanksi administratif ini, Bapepam perlu memperhatika aspek pembinaan ter- hadap pihak yang dimaksud. Pihak yang dimaksud adalah emiten, perusahaan publik, bursa efek, lembaga kliring dan penjamin, lembaga penyimpaan dan penyelesaian (LPP), reksa dana, wakil perantara, pedagang efek, wakil manejer investasi, biro administrasi efek, custodian, wali amanat, profesi penunjang pasar modal, dan pihak lain yang memperoleh ijin, persetujuan dan pendaftaran dari Bapepam.

Ketentuan ini juga berlaku bagi direktur, komisaris dan setiap pihak yang memiliki sekurang-kurangnya 5\% saham emiten atau perusahaan publik sebagaimana yang diamksud dalam pasal 87 Undang-undang Pasar Modal.

Selain itu, dalam pasal 107 Undang-undang Pasar Modal menegaskan bahwa setiap pihak yang senga- ja bertujuan menipu atau merugikan pihak lain atau menyesatkan Bapepam, menghilangkan, memusnahkan, mengubah, mengaburkab, menyembunyikan atau memalsukan catatan atau pihak yang memperoleh ijin, persetujuan atau pendaftaran dari Bapepam termasuk emiten dan perusahaan public diancam dengan pidana penjara paling lama 3 (tiga) tahun dan denda paling banyak Rp. 5.000.000.000,00 (lima milyar rupiah).

Dalam pasal 80 Undang-undang pasar modal No. 8 tahun 1995 menyebutkan:

1. Jika pernyataan pendaftaran dalam rangka penawaran umum memuat informasi yang tidak benar tentang fakta material atau tidak memuat informasi tentang fakta material sesuai dengan ketentuan undang-undang ini dan atau peraturan pelaksanaannya sehingga informasi dimaksud menyesatkan, maka:

a. Setiap pihak yang menandatangani pernyataan pendaftaran.

b. Direktur dan komisaris emiten pada waktu pernyataan pendaftaran menjadi efektif

c. Penjamin pelaksanaan emiten efek, dan

d. Profesi penunjang pasar modal atau pihak lain yang memberikan pendapat atau keterangan dan atas persetujuan dimuat dalam pernyataan pendaftaran, wajib bertanggungjawab, baik sendiri-sendiri maupun bersama-sama atas kerugian yang timbul akibat perbuatan dimaksud. 
2. Pihak sebagaimana dimaksud dalam ayat (1) huruf $d$ hanya bertanggungjawab atas pendapat atau keterangan yang diberikannya.

3. Ketentuan sebagaimana dimaksud dalam ayat (1) tidak berlaku dalam hal pihak sebagaimana dimaksud dalam ayat (1) huruf $\mathrm{c}$ dan huruf d dapat membuktikan bahwa pihak yang bersangkutan telah bertindak secara professional dan telah mengambil langkah-langkah yang cukup untuk memastikan bahwa:

a. Pernyataan atau keterangan yang dimuat dalam pernyataan pendaftaran adalah benar, dan

b. Tidak ada fakta material yang diketahuinya yang tidak dimuat dalam pernyataan pendaftaran yang diperlukan agar pernyataan pendaftaran tidak menyesatkan.

4. Tuntutan ganti rugi dalam hal terjadi pelanggaran sebagaimana dimaksud dalam ayat (1) hanya dapat diajukan dalam jangka waktu 5 (lima) tahun sejak pernyataan pendaftaran tersebut.

Selanjutnya diterangkan dalam pasal 81 Undangundang Pasar Modal No. 8 Tahun 1995 adalah:

1. Setiap pihak yang menawarkan atau menjual efek dalam menggunakan prosfektus atau dengan cara lain, baik tertulis maupun lisan, yang memuat informasi yang tidak benar tentang fakta material atau tidak memuat informasi tentang fakta material dan pihak tersebut mengetahui atau sepatutnya mengetahui mengenai hal tersebut wajib bertanggungjawab atas kerugian yang timbul akibat perbuatan dimaksud.

2, Pembelian efek yang telah mengetahui bahwa informasi tersebut tidak benar dan menyesatkan sebelum melaksanakan pembelian efek tersebut tidak dapat mengajukan tuntutan ganti rugi terhadap kerugian yang timbul dari transaksi efek dimaksud.

Dari uraian pasal diatas dapat dilihat bahwa pada dasarnya keterbukaan informasi dalam kegiatan pa-

sar modal dilakukan oleh lembaga penunjang pasar modal, dan tanggungjawab masing-masing profesi penunjang pasar modal tersebut terbatas pada pendapat atau keterangan yang diberikannya dalam rangka pernyataan pendaftaran. Oleh karena itu pemodal hanya dapat menuntut ganti rugi atas kerugian yang timbul dari pendapat atau penilaian yang diberikan profesi penunjang pasar modal tersebut.

Penjamin pelaksana emisi efek atau profesi penunjang pasar modal tidak dapat dituntut ganti rugi atas kerugian yang diderita oleh pemodal apabila penjamin pelaksana emisi efek atau profesi penunjang pasar modal tersebut telah melakukan penilaian atau memberikan pendapatnya secara professional, dalam arti pekerjaaannya telah dilaksanakan sesuai dengan norma pemeriksaan, prinsip-prinsip dan kode etik masing-masing profesi, dan pendapatnya atau penilaiannya itu telah diberikan secara independen. selain itu, penjamin pelaksana emisi efek atau profesi penunjang pasar modal telah melakukan langkahlangkah kongkrit yang diperlukan untuk memastikan kebenaran dari pernyataan atau keterangan yang diungkapkan dalam pernyataan pendaftaran.

Sejak tahun 1997 pemerintah mulai mencoba mengaktifkan bursa saham yang sebenarnya telah dikenal setelah Perang Dunia II, kegiatan hingga tahun 1987 bersifat sporadis, transaksi berlangsung amat sedikit, sementara perusahaan-perusahaan yang ikut dibursa terdorong untuk memenuhi ketetapan Penanaman Modal Asing (PMA) yang mengharuskan partisipasi saham domestic. Sejak tahun 1988 terutama sejak bulan oktober 1988, dipasar modal Jakarta bergerak amat aktif dan dibuka juga bursa paralel (Over The Confer) dan bursa efek Surabaya.

Pasar modal merupakan dasar dari bursa saham yang diperjualbelikan antara para investor dikatakan efisien apabila informasi mengenai harga saham yang tersedia di lantai bursa. Hal tersebut berarti bahwa seluruh strategi perdagangan dibursa berdasarkan informasi yang tersedia, sehingga dapat diperkirakan mengenai keuntungan serta resiko yang terdapat di dalamnya.

Sumantoro mengatakan bentuk yang efisien dari pasar secara garis besar dapat dibedakan menjadi tiga yaitu $^{10}$ :

\footnotetext{
${ }^{10}$ Sumantoro, Pengantar Tentang Pasar Modal Indonesia, Jakarta: Ghalia Indonesia, 1990 hal 1
} 
1. Weakform efficiency, yaitu berkenaan dengan informasi mengenai harga saham yang telah lama

2. Semi strong from efficiency, yaitu berkenaan dengan aanya informasi yang diumumkan kepada masyarakat,

3. Strong form efficiency, yaitu berkenaan dengan seluruh informasi yang bagi masyarakat termasuk mengenai informasi orang dalam.

Perbedaan efisiensi pasar diatas adalah tentang keberadaan saham-saham, baik itu tentang asal usulnya dengan segal sesuatu yang secara umum diketahui masyarakat perihal sesuatu saham. Hal tersebut diperlukan untuk memberikan perlindungan hukum dalam kegiatan memperdagangkan saham yang dimaksud.

Efisiensi dalam transaksi efek merupakan salah satu bentuk insentif bagi calon emiten, maupun calon investo beli atau jual. Cepatnya transaksi, murahnya biaya pencatatan (listing fee), biaya penitipan pada bank custodian serta sistim pengawasan yang cepat dan tepat akan menciptakan dinamika pasar modal.

Pelanggaran terhadap aturan main dalam transaksi efek sering disebabkan karena kelemahan sistim pengawasan yang dilakukan pihak pengelola bursa maupun pengawas bursa, sehingga apabila terjadi pelanggaran transaksi efek baik karena manipulasi, informasi yang menyesatkan maupun insider trading sulit terdeteksi secara dini.

Kegiatan bursa saham, apabila diukur, lebih merupakan objek hukum, artinya para ahli hukum perlu lebih banyak tampil. Hukum yang mengatur kegiatan pasar modal mencakup ketentuan mengenai persyaratan perusahaan yang menawarkan saham atau obligasi kepada masyarakat, ketentuan pedagang perantara profesi penunjang, lembaga penunjang, perlindungan investor serta aturan main pasar modal.

Persyaratan tersebut dibuat dalam rangka memberikan pemahaman kepada masyarakat tentang keadaan perusahaan yang melakukan emisi. Perusahaan tersebut harus menyampaikan segala fakta material atau harus terbuka kepada masyarakat.

Permasalahan yang timbul adalah menjaga keseimbangan antara kepentingan perusahaan untuk menjaga rahasia perusahaan disatu pihak dan hak-hak pemegang saham untuk melindungi investasi mereka di pihak lain. Sehingga hal tersebut merupakan suatu dilema, hukum disatu pihak mengejar dengan memerinci sedetil-detilnya tentang hal-hal apa saja yang mesti didisclose oleh pihak-pihak penyandang kewajiban disclosure. Di pihak lain, hukum juga harus memproteksi kepentingan-kepentingan tertentu dari pihak yang diwajibkan membuka informasi saham. Perusahaan tersebut harus menyampaikan segala fakta material atau harus terbuka kepada msyarakat.

Praktek perdagangan yang menggunakan informasi yang belum terbuka untuk umum ternyata banyak yang tidak dapat terjaring dengan ketentuan insider trading dalam transaksi efek. Masalah tersebut bermula pada batasan insider trading antara Negara yang satu dengan yang lainnya berbeda.

Pasal 95 Undang-undang Pasar Modal No. 8 Tahun 1995 memberikan peluang bagi pihak lain yang tidak termasuk kategori orang dalam, melakukan transaksi saham perusahaan yang bersangkutan berdasarkan informasi tidak langsung atau disebut dengan istilah tippee".

Pengertian insider trading dalam Undang-undang Pasar Modal tersebut secara tidak langsung menerapkan pengertian insider trading berdasarkan fiduciary theory yang berlaku di Amerika Serikat. Teori tersebut tidak mampu menjaring praktek insider trading yang dilakukan oleh bukan orang dalam. Tetapi memperoleh informasi secara tidak langsung atau tidak sengaja dari orang dalam keadaan tersebut merupakan salah satu penyebab sulitnya menelusuri praktek insider trading. Di Amerika Serikat kelemahan teori tersebut dapat diatasi dengan misappropriation theory, sehingga orang yang secara tidak sengaja memperoleh informasi material dari orang dalam, dapat terkena ketentuan insider trading.

Larangan terhadap orang dalam tidak dikenakan kepada perusahaan efek (perusahaan yang melakukan kegiatan usahanya sebagai penjamin emisi efek, perantara pedagang efek dan atau manejer investasi) dengan kata lain bahwa perusahaan efek tersebut di- 
lakukan bukan atas tanggungannya sendiri tetapi atas perintah nasabahnya dan perusahaan efek tersebut tidak memberikan rekomendasi kepada nasabahanya mengenai efek yang bersangkutan.

Bila dibandingkan dengan Negara lain yang telah memiliki undang-undang yang melarang perdagangan orang dalam secara khusus, tampak bahwa aturan mengenai perdagangan orang dalam yang terdapat di Indonesia memang masih minim yaitu hanya merupakan sebagian dari bab yang mengatur tentang penipuan, manipulasi pasar dan perdagangan orang dalam. namun demikian bila dibandingkan dengan Undang-undang Pasar Modal yang lama yaitu (Undang-Undang No. 15 Tahun 1952 tentang Penerapan Undang-undang Darurat Tentang Bursa sebagai Undang-undang), hal ini sudah merupakan suatu kemajuan dalam aturan transaksi efek, dan didalam penjelasan undang-undang tersebut diuraikan secara cukup luas bahkan jauh lebih luas dari ketentuan pada peraturan-peraturan sebelumnya.

Dalam undang-Undang Pasar Modal No. 8 Tahun 1995 dicantumkan juga ancaman pidana penjara paling lama 10 (sepuluh) tahun dan denda setingi-tingginya 15 milyar. Dengan melihat ancaman pidana tersebut dapat dikatakan bahwa perdagangan orang dalam terebut dikategorikan kedalam tindak pidana kejahatan.

Kemajuan ini terlihat pula dengan diberinya wewenang bagi Bapepam untuk melakukan kegiatan pemeriksaan dan penyidikan atas pelanggaran tersebut, sebagaimana dicantumkan dalam Undang-Undang No. 8 Tahun 1995 (dalam hal ini khususnya tentang perdagangan orang dalam) yang menagkibatkan kerugian pemodal atau masyarakat maka Bapepam dapat menetapkan dimulainya tindakan penyidikan.

Untuk melakukan penyidikan ini maka pejabat pegawai negeri sipil dilingkungan Bapepam diberi wewenang khusus untuk melakukan penyidikan tindak pidana di bidang pasar modal. Hal mana tentunya dikaitkan dengan ketentuan yang berlaku.

\section{Kesimpulan}

1. Penerapan prinsip keterbukaan informasi pada perusahaan yang akan melakukan penawaran di pasar modal menurut Pasal 1 angka 25 UU No. 8 Tahun 1995 adalah keharusan bagi emiten un- tuk menginformasikan kepada masyarakat dalam waktu yang tepat seluruh informasi material mengenai usahanya. Emiten juga berdasarkan Pasal 86 ayat 1 UU No. 8 Tahun 1995 harus menyampaikan informasi penting yang berkaitan dengan tindakan atau efek dalam bentuk laporan berkala dan laporan peristiwa penting.

2. Bapepam dapat mengenakan sanksi kepada emiten yang berdasarkan Pasal 102 ayat (2) UU No. 8 Tahun 1995 berupa tindakan administratif yaitu: peringatan tertulis, denda yaitu kewajiban untuk membayar sejumlah uang tertentu, pembatasan kegiatan usaha, pembekuan kegiatan usaha, pencabutan izin usaha, pembatalan persetujuan dan pembatalan pendaftaran.

\section{Saran}

1. Undang-Undang No. 8 Tahun 1995 sudah selayaknya dirubah dan memuat ketentuan pidana sebagaimana hukum yang bersifat lex specialis. Pelaku Tindak Pidana dalam hubungannya dengan prinsip keterbukaan informasi dapat diproses Pelaku Insider Trading.

2. Untuk memberikan rasa aman bagi investor untuk melakukan emisi saham perlu diupayakan perlindungan hukun melalui mekanisme Transparansi Informasi (Full Disclosure Principle). Larangan manipulasi termasuk larangan insider trading.

\section{Daftar Pustaka}

A Abdulrahman, Ensiklopedia Ekonomi Keuangan dan Perdagangan, Jakarta: Pradnya Paramita, 1991.

Anisitus Amanat, Pembahasan UU Perseroan Terbatas 1995 dan Penerapannya Dalam Akta Notaris, Jakarta: Raja Grafindo Persada, 1995.

Sofyan A Djalil, Perlindungan Investor Di Pasar Modal. Yogyakarta: Fakultas Hukum Univesitas Gadjah Mada, 1997.

Munir Fuady, Pasar Modal Modern, Tinjauan Hukum (Buku 1). Bandung: Citra Aditya Bakti, 1996. 
, Pasar Modal Modern,

Tinjauan Hu- kum (Buku 2).

Bandung: Citra Aditya Bakti, 1996.

Najib A Gisymar, Insider Trading Dalam Transaksi Efek, Bandung: Citra Aditya Bakti, 1996.

C. S. T. Kansil \& Christine Kansil, PokokPokok Per- seroan Terbatas Tahun 1995, Jakarta: Pustaka Sinar Harapan, 1996.

Abdul Muis, Pengantar Hukum Dagang. Medan: Fakultas Hukum Universitas Sumatera Utara, 1996.

Asril Sitompul, Pasar Modal Penawaran Umum dan Permasalahannya, Bandung: Citra Aditya Bakti, 1996.

B. De. Smelen, Bursa Efek, Perusahaan Efek dan Lalu Lintas Efek, Jakarta: Pradnya Paramita, 1997.

Sumantoro, Pengantar Tentang Pasar Modal Indo- nesia, Jakarta: Ghalia Indonesia, 1990. 